\title{
Cytotoxic Effects of Resin Components on Cultured Mammalian Fibroblasts
}

\author{
C.T. HANKS, S.E. STRAWN, J.C. WATAHA ${ }^{1}$, and R.G. CRAIG ${ }^{1}$
}

\author{
Departments of Oral Medicine, Pathology and Surgery, and 'Biological and Materials Sciences, School of Dentistry, University \\ of Michigan, Ann Arbor, Michigan 48109-1078
}

The objectives of this study were to determine the cytotoxic concentrations of 11 components of resin composites on monolayers of cultured Balb/c 3T3 fibroblasts, to study the inhibitory effects of these components on DNA synthesis, total protein content, and protein synthesis, and to determine whether effects were reversible when the components were withdrawn from the medium. These data were reported as concentrations which inhibited $10 \%\left(\mathrm{ID}_{10}\right)$ and $50 \%\left(\mathrm{ID}_{50}\right)$ of a particular metabolic process as well as the range of concentrations over which cell metabolism was irreversibly inhibited. For any individual component, the $\mathrm{ID}_{50}$ values for all three metabolic parameters were of the same magnitude. The same was true for the ranges of irreversibility. Ethoxylated Bis-phenol A dimethacrylate (E-BPA) was the most toxic molecule of the group (ID ${ }_{50}$ being between 1 and $10 \mu \mathrm{mol} / \mathrm{L}$ ). The $\mathrm{ID}_{50}$ concentrations for three of the components, including Bis-GMA, UDMA, TEGDMA, and $B$ is-phenol $A$, ranged between 10 and $100 \mu \mathrm{mol} / \mathrm{L}$, while the $\mathrm{ID}_{50}$ values of three components ( $N, N$ dihydroxyethyl-p-toluidine, camphoroquinone, and $\mathrm{N}, \mathrm{N}$ dimethylaminoethyl methacrylate) were above $100 \mu \mathrm{mol} / \mathrm{L}$. The concentrations to which the cells and tissues are exposed in vivo are not known. This study should help to identify the concentrations of organic composite components which pose clinical cytotoxic hazards.

\section{J Dent Res 70(11):1450-1455, November, 1991}

\section{Introduction.}

Although physical properties of resin composites are constantly being improved, in vivo studies have shown that the use of these resins as restorative materials is occasionally associated with necrosis and irritation of the pulp (Stanley et al., 1967; Baume and Fiore-Donno, 1968; Tobias et al., 1973; Stanley et al., 1975; Block et al., 1977) as well as the periodontium (Nasjleti et al., 1983). Other studies support the concept that microleakage of bacteria around these composite restorations, rather than the composites themselves, is responsible for pulpal inflammation (Brännström and Nyborg, 1972; Bergenholtz et al., 1982; Cox et al., 1987).

Stanley et al. (1979) reported that most of eight individual components of resin composites failed to cause significant necrosis and inflammation when placed for 21 days on pulpal dentin walls of about 1-mm thickness in class $V$ cavity preparations in monkey teeth. Other investigators have shown that resin composites are capable of releasing components which cause toxic reactions in vitro. In a study of four resin composites (Hanks et al., 1988), aqueous-medium-extracted components diffused through dentin to cause a cytotoxic response within the first $24 \mathrm{~h}$ in a 72 -hour study. Ferracane and Condon (1990) found that $50 \%$ of the leachable species from the composite Silux ${ }^{\circledR}$ was eluted within three $h$ of its being soaked in water, and from 85 to $100 \%$ was eluted within $24 \mathrm{~h}$. A mixture of ethanol and water was even more effective. More components were removed than by water alone, and $75 \%$ of them were removed within three h. Rathbun et al. (1991) tested the cytotoxicity (depression of protein synthesis) of a Bis-GMA composite (Silar () ) before and after extraction with ethanol, chloroform, or

Received for publication March 12, 1991

Accepted for publication June 26, 1991

This investigation was supported in part by USPHS Research Grants DE-09296 and DE-07987. toluene. The extraction of unreacted components with these solvents reduced the cytotoxic effect of the composite by about $90 \%$. The major unreacted component was identified as Bis-GMA oligomer, although 2-hydroxy-4-methoxybenzophenone and the phenyl ester of benzoic acid could be detected.

Because there have been no realistic estimates of the concentrations of composite components achieved in either dentinal tubule fluid, saliva, or connective tissue, it was decided to study the possible cytotoxic effects of a number of components to determine the concentrations which could pose a cellular risk. Therefore, the objectives of the present study were (a) to determine for 11 components the concentrations which could be described as cytotoxic; (b) to study the cytotoxic effects of these components on two major macromolecular synthetic processes, DNA, and protein synthesis; and (c) to determine whether these effects were reversible when the material was removed from the environment.

\section{Materials and methods.}

The 11 components of restorative resins used in this study are shown in the Table. $100 \%$ DMSO (Fisher Scientific, certified grade) was used to dissolve the stock components. Each stock concentration was then diluted 1000 times with medium so that the final concentration of DMSO was $0.1 \%$, a concentration which gave no statistical variation from control wells with any metabolic parameter tested.

When the materials being tested were in solution, visible and UV spectra (Beckman DU-64 spectrophotometer; Beckman Instruments, Inc., Fullerton, CA) were determined on various stock concentrations of the components in DMSO and of dilutions of 1:1000 in water. All components, except for ethoxylated Bis-phenol A dimethacrylate (E-BPA), showed no spectral turbidity. The stock solution of 0.3 $\mathrm{mol} / \mathrm{L}$-BPA in DMSO showed minor turbidity, indicating that not all of it was dissolved. The stock solution was used to make serial non-turbid dilutions, which were added to the cells $(1 \mu \mathrm{L} / 1 \mathrm{~mL} /$ well $)$.

Wells of 24-well dishes (Costar, Cambridge, MA) were plated with Balb/c 3T3 cells derived from clone A31 (ATCC CCL 163; Rockville, MD) at 15,000 cells $/ \mathrm{cm}^{2}$. The medium used for culture was Dulbecco's minimum essential medium (DMEM) with $4500 \mathrm{mg} / \mathrm{L}$ glucose (Flow Laboratories, McLean, VA), 3\% Nu-Serum (Collaborative Research, Bedford, MA), and supplements (2 mmol/L glutamine, 125 units/mL penicillin, $125 \mu \mathrm{g} / \mathrm{mL}$ streptomycin; Gibco, Grand Island, NY). The resin components were added $24 \mathrm{~h}$ after the cells were plated $(t=0)$, and were assessed at eight and $24 \mathrm{~h}$. Reversibility was determined by removal of the medium from selected wells and its replacement with fresh medium for an additional $24 \mathrm{~h}$. Baseline metabolic values were evaluated at all time intervals. Six replicate wells were used for each concentration. Analysis of variance, with Tukey pair-wise comparisons, was used to determine whether the effects of the resin components were significant at the $95 \%$ confidence level.

Metabolic activity of the cells was assessed by use of tritiated thymidine $\left({ }^{3} \mathrm{H}-\mathrm{TdR}\right)$ incorporation, tritiated leucine $\left({ }^{3} \mathrm{H}\right.$-leu $)$ incorporation, and the total protein content of each well. Simple medium containing either ${ }^{3} \mathrm{H}$-TdR or ${ }^{3} \mathrm{H}$-leu was added as $20-\mu \mathrm{L}$ aliquots to "pulse"-label the cultures. The concentration of each isotope was 5 $\mu \mathrm{Ci} / \mathrm{mL}$ in each well. The stock ${ }^{3} \mathrm{H}$-leu was $5 \mathrm{mCi}$ in $5 \mathrm{~mL}$ of $0.01 \mathrm{~mol} /$ $\mathrm{L} \mathrm{HCl}$ (specific activity $=64 \mathrm{Ci} / \mathrm{mmol}$; ICN Radiochemicals, Irvine, CA). The stock ${ }^{3} \mathrm{H}-\mathrm{TdR}$ was $5 \mathrm{mCi}$ in $5 \mathrm{~mL}$ sterile water (specific 


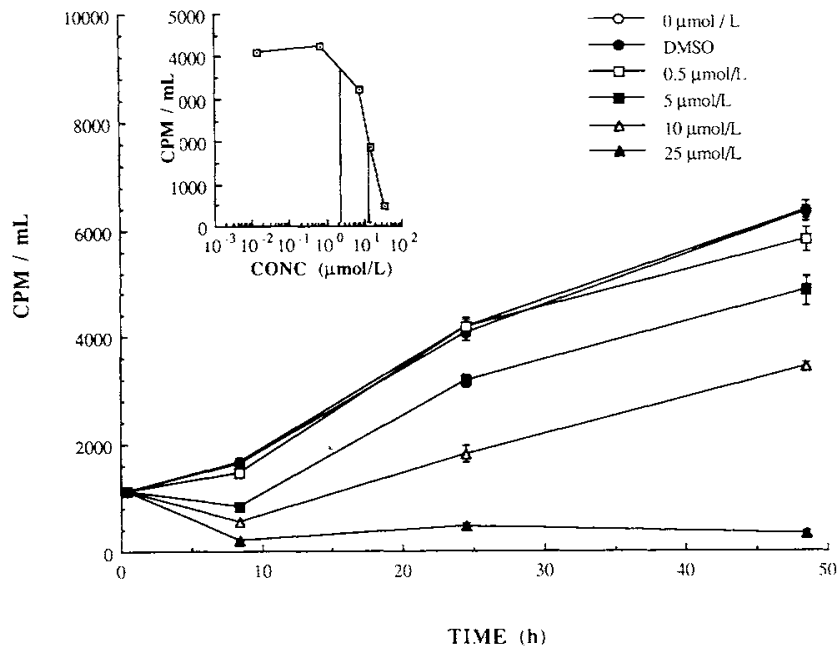

Fig. 1-The effects of four concentrations of Bis-GMA $(0.5-25 \mu \mathrm{mol} / \mathrm{L})$ as well as $0.1 \%$ DMSO, in comparison with those of untreated controls $(0 \mu \mathrm{mol} /$ $\mathrm{L}$ ), on DNA synthesis ( ${ }^{3} \mathrm{H}-\mathrm{TdR}$ incorporation into DNA) in monolayer cultures of $\mathrm{Balb} / \mathrm{c} 3 \mathrm{~T} 3$ cells. The cells were plated in complete medium plus ${ }^{3} \mathrm{H}-\mathrm{TdR} 24 \mathrm{~h}$ prior to the 0 time point. At time 0, either Bis-GMA or DMSO was added to each well. Each point represents the mean concentration and standard error of the mean (vertical bars) of six wells. The points representing $0 \mu \mathrm{mol} / \mathrm{L}$ Bis-GMA are not visible because of the overlay of graphs. At 24 $h$, fresh medium without the above additives was placed into the respective sets of wells for the next $24 \mathrm{~h}$ to determine whether the effects were reversible. The inset shows the concentrations representing $\mathrm{ID}_{10}$ (lower concentration) and $\mathrm{ID}_{50}$ (higher concentration) doses of Bis-GMA for DNA synthesis at $24 \mathrm{~h}$.

acitivity $=6.7 \mathrm{Ci} / \mathrm{mmol} ;$ ICN Radiochemicals $)$. In order that the lack of thymidine did not limit the rate of DNA synthesis, the total thymidine - including radioisotope-labeled thymidine - was brought to $5 \mu \mathrm{mol} / \mathrm{L}$ with cold thymidine for a 45 -minute pulse.

For the protein synthetic assay, ${ }^{3} \mathrm{H}$-leu was added to each well for $90 \mathrm{~min}$ before harvest. During harvesting, the medium was suctioned off, and the wells were washed twice with phosphate-buffered saline (PBS). Then, a solution of $0.25 \%$ Triton X-100 in $0.1 \mathrm{~mol} / \mathrm{L} \mathrm{NaOH}$ was used to lyse the cells, and aliquots were taken from each well and placed on cellulose nitrate filters (2.5-cm circles; Whatman $3 \mathrm{MM}$ ) for liquid scintillation. Other aliquots from each well were placed in glass test tubes, from which total protein per well was determined. The tubes for protein assay (BCA assay; Pierce, Rockford, IL) were read on a spectrophotometer at $562 \mathrm{~nm}$. For liquid scintillation, the filters were washed sequentially with $10 \%$ trichloroacetic acid $\left(\mathrm{TCA} ; 4^{\circ} \mathrm{C}\right), 5 \% \mathrm{TCA}\left(60^{\circ} \mathrm{C}\right), 5 \% \mathrm{TCA}\left(4^{\circ} \mathrm{C}\right)$, and dry acetone before being dried. A non-aqueous scintillation fluid (Biosafe NA, Research Products International Corp., Mt. Prospect, IL) was placed into the vials for counting.

For the assay of DNA synthesis, ${ }^{3} \mathrm{H}-\mathrm{TdR}$ was added for a 45 minute pulse. The medium was removed and the wells were washed, first with ice-cold PBS and then with $10 \%$ TCA $\left(4^{\circ} \mathrm{C}\right)$. Finally, $6.7 \mathrm{~mol} / \mathrm{L}$ perchloric acid $\left(\mathrm{PCA} ; 60^{\circ} \mathrm{C}\right.$ ) was added to each well for $30 \mathrm{~min}$, and the well contents were mixed before aliquots from each well were placed in LSC vials with Biosafe II (Research Products International Corp.) for scintillation counting.

\section{Results.}

The effects of a representative component, Bis-GMA oligomer, are shown in Figs. 1-3, wherein the resulting DNA synthesis, protein synthesis, and total protein, respectively, are given for cell monolayers exposed to five concentrations of the component for three different time intervals (through $24 \mathrm{~h}$ ) and then, after removal

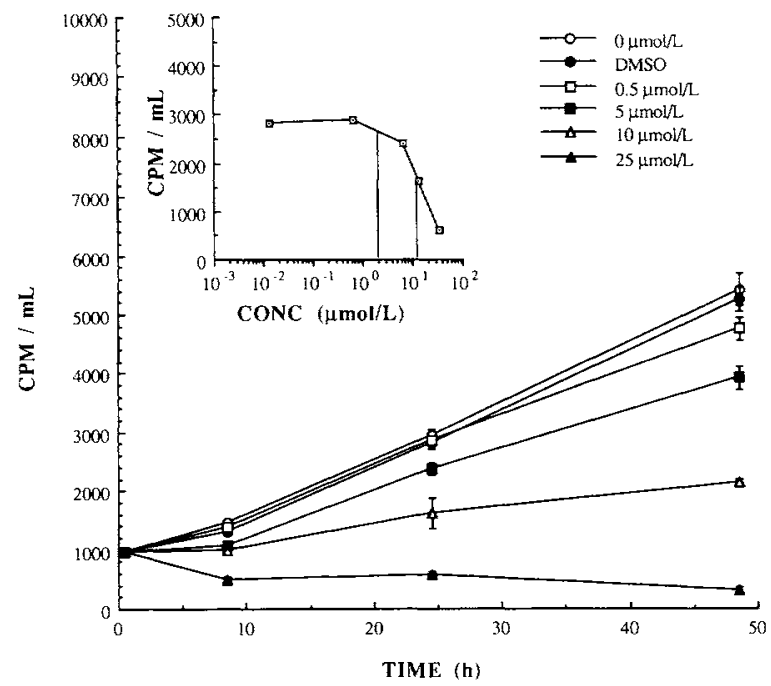

Fig. 2-The effects of Bis-GMA concentrations or $0.1 \%$ DMSO, in comparison with those of untreated controls, on protein synthesis $\left({ }^{3} \mathrm{H}-\mathrm{leu}\right.$ incorporation into protein) in Balb/c $3 \mathrm{~T} 3$ cell cultures under conditions similar to those for Fig. 1 . The inset shows the $\mathrm{ID}_{10}$ and $\mathrm{ID}_{50}$ doses at $24 \mathrm{~h}$.

of the component from the media, for the next $24 \mathrm{~h}$. In the study of the influence of Bis-GMA on DNA synthesis in Balb/c 3T3 cells (Fig. 1), there was no statistically significant difference between cells treated with $0.5 \mu \mathrm{mol} / \mathrm{L}$ Bis-GMA during the $24 \mathrm{~h}$ of treatment and the untreated control cells or cells treated with only $0.1 \%$ DMSO. However, $5 \mu \mathrm{mol} / \mathrm{L}$ Bis-GMA depressed DNA synthesis significantly $(\mathrm{p}=0.05)$ more than did lower concentrations at the 24-hour time period. The toxic effects of Bis-GMA on DNA synthesis were irreversible at some concentration between 10 and $25 \mu \mathrm{mol} / \mathrm{L}-$ i.e., at $25 \mu \mathrm{mol} / \mathrm{L}$, the line between 24 and $48 \mathrm{~h}$ had a negative slope. Fig. 1 (inset) shows these data as CPM/mL of radioisotope incorporated into DNA vs. concentration of Bis-GMA on a log scale. The concentration of Bis-GMA which caused inhibition of $10 \%$ of DNA synthesis as compared with untreated controls ( $\mathrm{ID}_{10}$ ) was $2.2 \mu \mathrm{mol} / \mathrm{L}$, and the $\mathrm{ID}_{50}$ was $13.0 \mu \mathrm{mol} / \mathrm{L}$.

There was no statistically significant difference in effect on

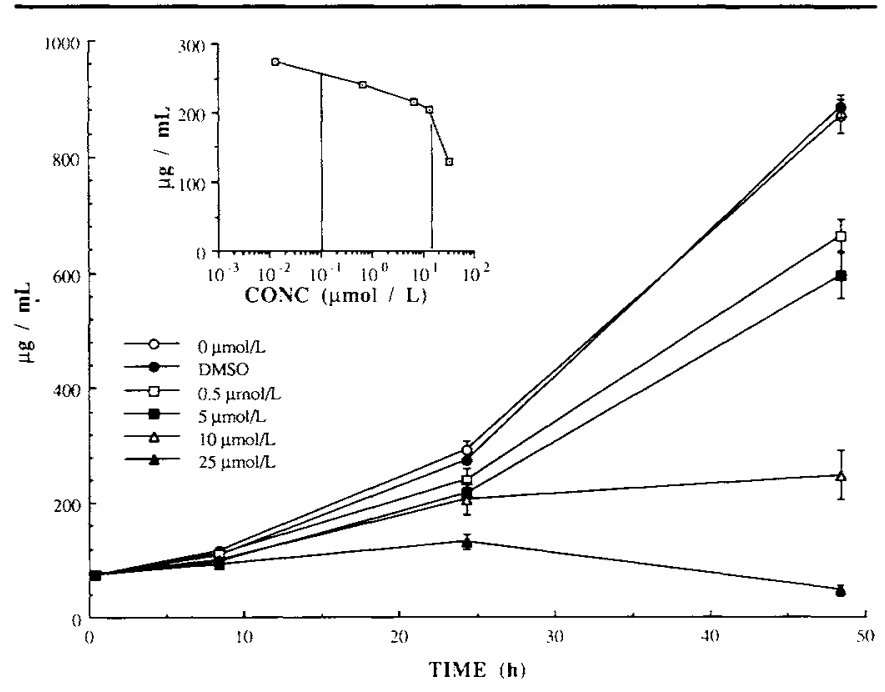

Fig. 3-The effects of Bis-GMA concentrations or $0.1 \%$ DMSO, in comparison with those of untreated controls, on total protein content of each well in Balb/c 3T3 cell cultures under conditions similar to those for Fig. 1. The inset shows $\mathrm{ID}_{10}$ and $\mathrm{ID}_{50}$ doses at $24 \mathrm{~h}$. 


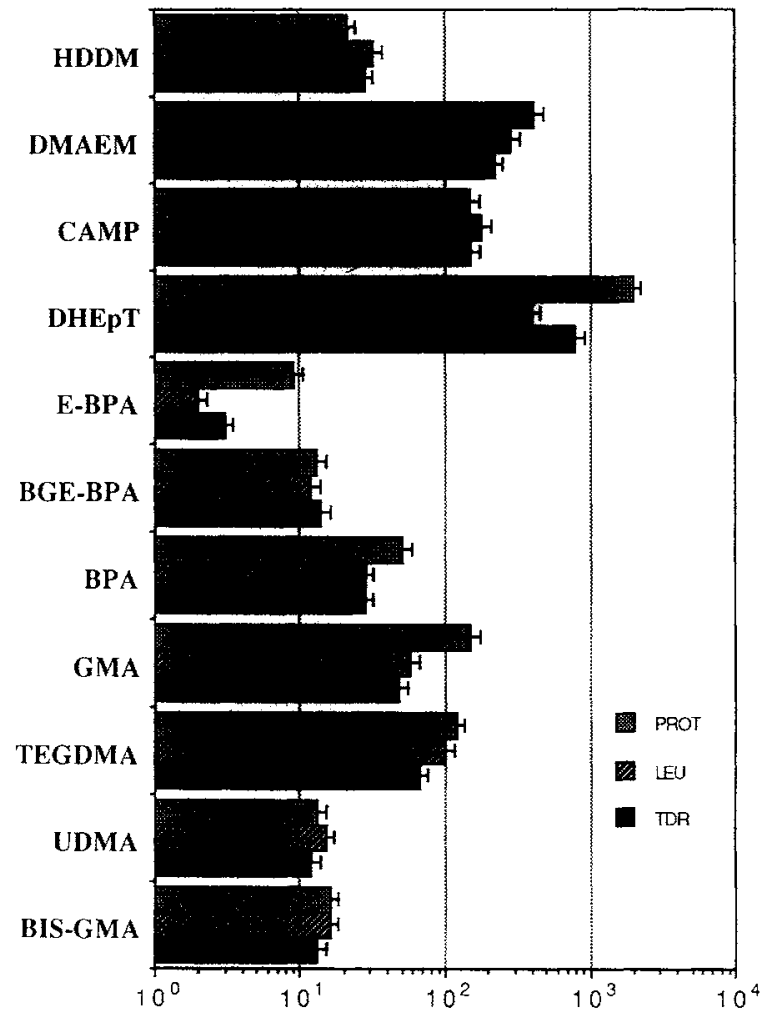

CONC. $(\mu \mathrm{mol} / \mathrm{L})$

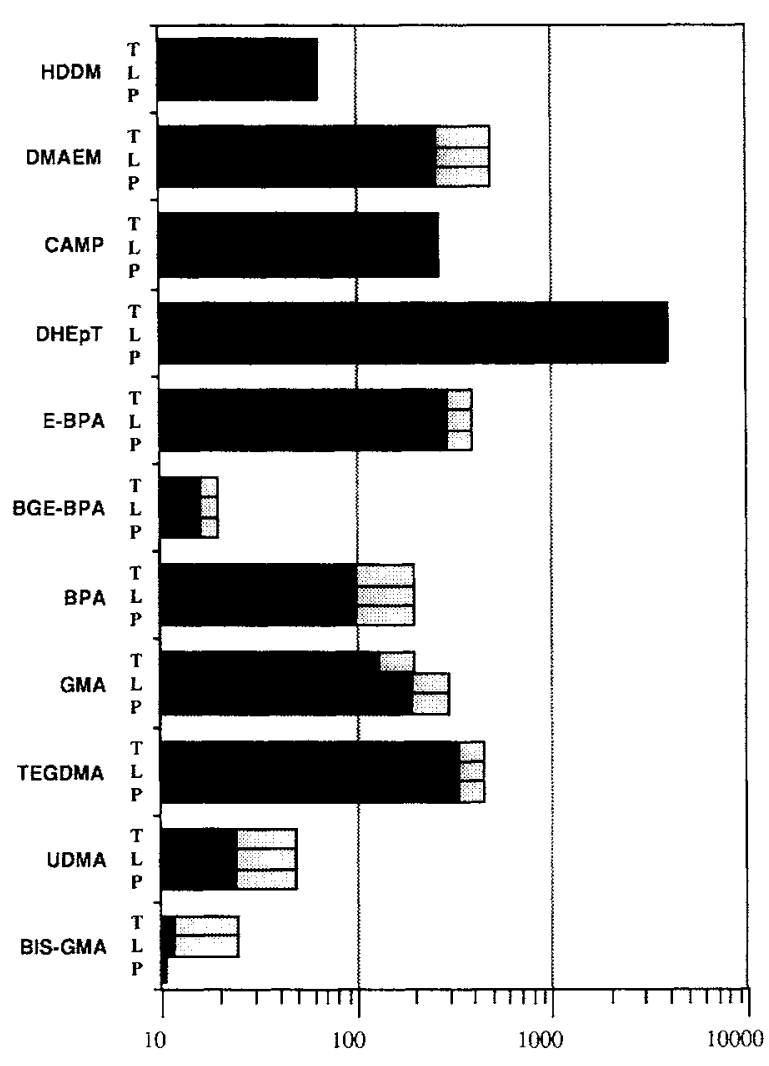

CONC. $(\mu \mathrm{mol} / \mathrm{L})$
Fig. 4-Comparison of $\mathrm{ID}_{50}$ values for each of 11 resin components for DNA synthesis (TDR), protein synthesis (LEU), and total protein per well (PROT). Error bars were determined graphically from cell-activity $v$ s. concentration curves and represent one standard error of the mean, $n=6$.

protein synthesis (Fig. 2) up to $24 \mathrm{~h}$ of treatment among the untreated controls and cells treated with $0.1 \% \mathrm{DMSO}$ or concentrations of $5.0 \mu \mathrm{mol} / \mathrm{L}$ Bis-GMA and below in $0.1 \%$ DMSO. The first statistical difference $(p=0.05)$ was observed between 5 and $10 \mu \mathrm{moV}$ $\mathrm{L}$ Bis-GMA at $24 \mathrm{~h}$. The toxic effects of Bis-GMA became irreversible between 10 and $25 \mu \mathrm{mol} / \mathrm{L}$. Fig. 2 (inset) shows that the $\mathrm{ID}_{10}$ and $\mathrm{ID}_{50}$ of Bis-GMA were $3.0 \mu \mathrm{mol} / \mathrm{L}$ and $16 \mu \mathrm{mol} / \mathrm{L}$, respectively.

For total protein remaining in each well (proportional to the number of cells present), the effect of $0.1 \%$ DMSO was no different from that of complete tissue culture medium at any time interval (Fig. 3). There was a significant decrease $(p=0.05)$ from untreated controls in total protein per well when $0.5 \mu \mathrm{mol} / \mathrm{L}$ Bis-GMA was placed in the well for 24-hour incubation, but this effect was reversible. The effect of Bis-GMA became irreversible between 10 and $25 \mu \mathrm{mo} / \mathrm{L}$. Fig. 3 (inset) also shows the 24-hour data for the effect of Bis-GMA on total protein in the well as $\mu \mathrm{g}$ protein $/ \mathrm{mL} v s$. concentration of Bis-GMA. The $\mathrm{ID}_{10}$ was $0.12 \mu \mathrm{mol} / \mathrm{L}$, while the $\mathrm{ID}_{50}$ was $16 \mu \mathrm{mol} / \mathrm{L}$.

The $\mathrm{ID}_{50}$ values, the range of concentrations between which the effects of Bis-GMA and the other components became irreversible for the three metabolic parameters, and the $\mathrm{ID}_{10}$ values are shown in Figs. 4-6, respectively. For each compound tested, the $\mathrm{ID}_{50}$ values for DNA synthesis were in the same order of magnitude as for protein synthesis (Fig. 4). The $\mathrm{ID}_{50}$ for either DNA or protein synthesis for only one component (E-BPA) ranged between 1 and 10 $\mu \mathrm{mol} / \mathrm{L}$. The $\mathrm{ID}_{50}$ for DNA and protein synthesis in the presence of seven components (Bis-GMA, UDMA, TEGDMA, GMA, BPA, BGE$B P A$, and $H D D M)$ ranged between 10 and $100 \mu \mathrm{mol} / \mathrm{L}$, and between 100 and $1000 \mu \mathrm{mol} / \mathrm{L}$ for three components (DHEpT, CAMP, and
Fig. 5-Irreversible effects on cell metabolism occurred in the range of concentrations between the darkly shaded bars (highest concentration with reversible effects) and lightly shaded bars (lowest concentration which caused irreversible effects). These ranges were determined from cellactivity $v s$. time curves, with $\mathrm{n}=6$ for each concentration tested. Lightly shaded bars are not shown for HDDM, CAMP, and DHEpT, because irreversible effects were not observed with these components. In these cases, the darkly shaded bar represents the highest concentration tested. Higher concentrations were not soluble.

DMAEM). The pattern for $\mathrm{ID}_{50}$ for total protein content in each well was similar to that of DNA or protein synthesis, except that the $\mathrm{ID}_{50}$ for GMA and DHEpT was almost one order of magnitude greater than that for the synthetic processes.

The range of irreversibility for any one component did not vary in order of magnitude among DNA synthesis, protein synthesis, and total protein (Fig. 5). The range of irreversibility of four components (Bis-GMA, UDMA, BGE-BPA, and HDDM) ranged between 10 and $100 \mu \mathrm{mol} / \mathrm{L}$ for all three metabolic measurements. For six components (TEGDMA, GMA, BPA, E-BPA, CAMP, and DMAEM), the range of irreversibility was between 100 and $1000 \mu \mathrm{mol} / \mathrm{L}$. Only for DHEpT was the range of irreversibility entirely above $1000 \mu \mathrm{mol} / \mathrm{L}$. For DHEpT, CAMP, and HDDM, no upper limit of the irreversibility range was observed in this study. Thus, the effects of these materials were reversible at all tested concentrations.

The earliest measure of cytotoxic effects, the $\mathrm{ID}_{10}$, was the most variable parameter (Fig. 6). The $\mathrm{ID}_{10}$ values were nearly the same for DNA and protein synthesis for five components (Bis-GMA, TEGDMA, BG-BPA, E-BPA, and CAMP). In only one case, UDMA, was the $\mathrm{ID}_{10}$ for DNA synthesis one order of magnitude less than that for protein synthesis. Conversely, for the five other components (GMA, BPA, DHEpT, DMAEM, and HDDM), the $\mathrm{ID}_{10}$ for protein synthesis was up to one order of magnitude less than that for DNA synthesis. Finally, the $\mathrm{ID}_{10}$ for total protein was in the same order 


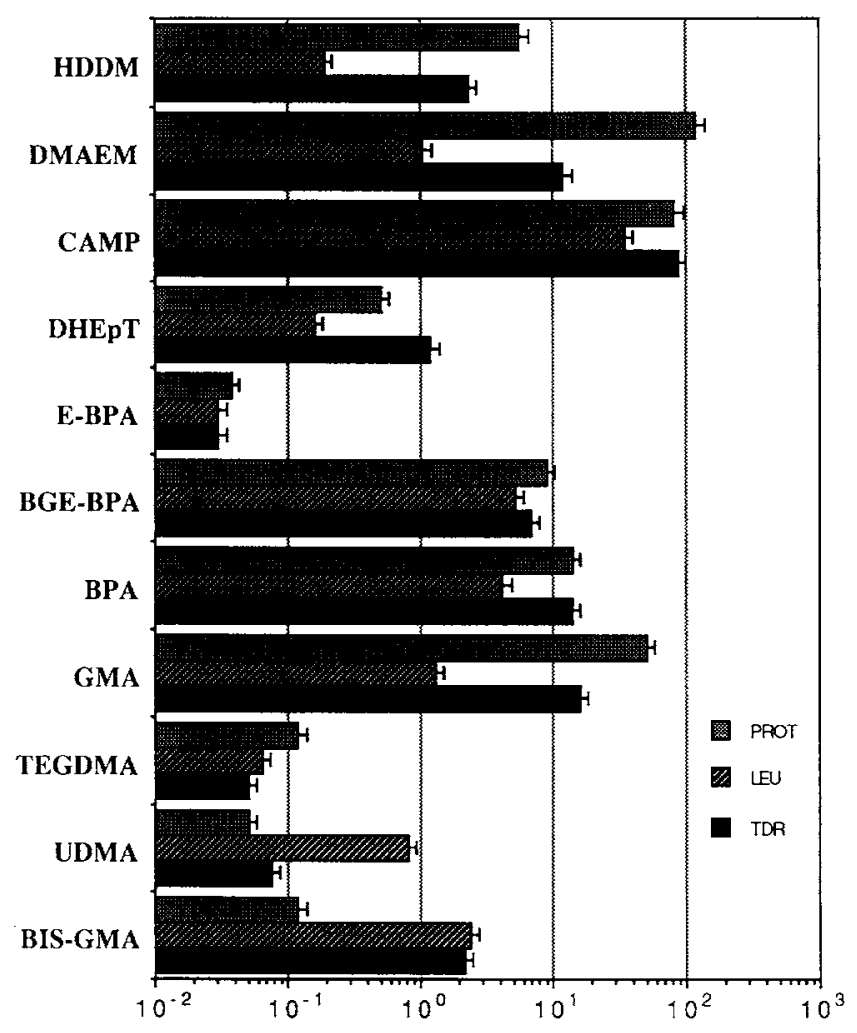

CONC. $(\mu \mathrm{mol} / \mathrm{L})$

Fig. 6-Comparison of $\mathrm{ID}_{10}$ values for each of 11 resin components for DNA synthesis (TDR), protein synthesis (LEU), and total protein per well (PROT). Error bars were determined graphically from cell-activity us. concentration curves and represent one standard error of the mean, $n=6$.

as, or one order of magnitude greater than, that for DNA synthesis for all but two components (Bis-GMA and DHEpT).

\section{Discussion.}

The value of this type of study is that the cytotoxicities of soluble materials can be observed under identical conditions. The use of a direct-contact assay gives absolute cellular responses to absolute concentrations, under the conditions of the test, rather than rankorder data (Hensten-Pettersen and Helgeland, 1981). This is contrary to data derived from tests such as agar overlay (Guess et $a l ., 1965)$ and Millipore filter (Wennberg et al., 1979) assays, where arbitrary materials were used to protect the test cell system from artifacts due to crushing by the sample, but which additionally filtered the test sample and diluted it to an unknown concentration. The methods used in the present study were similar to the ${ }^{51} \mathrm{Cr}$ release assay in the direct measurement of the effects of the soluble components of the test sample. The difference is that the present methods measured the effects on intracellular macromolecular synthetic processes, which are cycling events in living cells, while ${ }^{51} \mathrm{Cr}$-release measures permeability of cell membranes, which increases as the cell loses its ability to maintain a semi-permeable barrier, which is often a terminal event.

These stock chemical components are those used by companies which fabricate resin composites for sale to the dental industry. For test purposes, these chemicals were diluted at least 1:1000, which further diluted any contaminants to trivial levels. There is no doubt that the reductions in DNA and protein synthesis observed with these chemicals led to cell death when the concentrations were high enough, because the cells rounded up, came off the substrate, and had no measurable respiratory activity. In basic toxicology, the relative toxicities of chemicals are compared by the relative amounts of the chemicals per $\mathrm{kg}$ human or animal body weight which will kill half $\left(\mathrm{LD}_{50}\right)$ the animals to which they are administered (Gosselin $e t$ al., 1984; Lu, 1985). Thus, if the $\mathrm{LD}_{50}$ for a chemical is less than 5 $\mathrm{mg} / \mathrm{kg}$, then it is considered "supertoxic", and if the $\mathrm{LD}_{50}$ is between 5 and $15 \mathrm{~g} / \mathrm{kg}$, then it is only "slightly toxic". Because we have no clinical data as to how much of these components are extracted per volume of aqueous solutions and the subsequent toxicity of these solutions, we have chosen a concept similar to "degrees of toxicity" by noting the orders of magnitude of cytotoxicity for these 11 chemicals. We believe that this strategy will improve inter-laboratory repeatability.

The $\mathrm{ID}_{50}$ values (Fig. 4) are derived from activity-concentration graphs (Figs. 1-3, insets), and are probably the most useful of the indicators of cytotoxicity. The $\mathrm{ID}_{50}$ value is somewhere in the midrange between the earliest sign of cytotoxicity $\left(\mathrm{ID}_{10}\right)$ and the dose at which there is no metabolic activity (cell death). In the present study, for each component, the $\mathrm{ID}_{50}$ values for DNA and protein synthesis at $24 \mathrm{~h}$ were similar in magnitude, indicating that neither of these two parameters was more indicative than the other for the cytotoxic effects, under the present experimental conditions. One component, ethoxylated Bis-phenol A dimethacrylate, was cytotoxic in the 1-10 $\mu \mathrm{mol} / \mathrm{L}$ concentration range. Most fell within the 10-100 $\mu \mathrm{mol} / \mathrm{L}$ range, indicating that they were slightly less cytotoxic. These included the oligomers and monomers listed in the Table, except E-BPA. The similarities in $\mathrm{ID}_{50}$ values may be related to the structural similarity of these compounds. The two accelerators (DHEpT and DMAEM) and the photo-initiator, camphoroquinone, were even less cytotoxic, i.e., above $100 \mu \mathrm{mol} / \mathrm{L}$. No special effort was made to introduce UV light to cultures containing camphoroquinone.

The $\mathrm{ID}_{10}$ dose at $24 \mathrm{~h}$ was estimated similarly to that of the $\mathrm{ID}_{50}$ dose. This dose was used to quantify the lowest concentration at which cytotoxicity was manifested. Again, there was a great deal of similarity between the $\mathrm{ID}_{10}$ values of each component for DNA and protein synthesis. The $\mathrm{ID}_{10}$ for DNA synthesis, protein synthesis, and total protein varied no more than one order of magnitude for all components except DMAEM. The ID ${ }_{10}$ values for UDMA, TEGDMA, and E-BPA were much less than the $\mathrm{ID}_{50}$ values. For these components, the cytotoxic effects would be expected to be much more graded than if the two values were closer together. This may imply the possibility of chronic toxicity, which would reduce metabolic function and make the cells or tissue more vulnerable to insults from other sources.

Just as it was impossible to determine the exact concentration at which cytotoxic effects were initiated, the concentration which was associated with cell death was also elusive. Cell death is both concentration- and time-dependent for any chemical. Therefore, we chose to indicate the range of concentrations between which cells did not recover their DNA or protein synthetic activity when new complete medium was introduced from 24 to $48 \mathrm{~h}$ of incubation, and called it the "range of irreversibility". Again, there was no difference in the degrees of magnitude for DNA synthesis, protein synthesis, or total protein per well for any one component. All but three components had definable ranges. For DHEpT, CAMP, and HDDM, the lower limit of the range could be measured, but the upper limit was not detected (Fig. 5).

Two recent studies indicate that components of resin composites have effects on biological membranes. Terakado et al. (1984) have shown that benzoyl peroxide, a catalyst for resin composites, was capable of converting polyunsaturated fatty acids and phospholipids to peroxides, especially in the presence of low concentrations of $\mathrm{Cu}^{2+}, \mathrm{Fe}^{2+}$, and $\mathrm{Fe}^{3+}$. This suggested a mechanism of action by a number of composite components on lipid layers of cell membranes. Those components capable of causing peroxide formation of lipids 
TABLE

COMPONENTS OF RESINS, THEIR ABBREVIATIONS, MOLECULAR WEIGHTS, AND LOT NUMBERS

\begin{tabular}{lllll}
\hline \hline Material & Abbreviation & Molec. Wt. & Use & Lot No. \\
\hline Bis Glycidyl Ether of Bis Phenol A & BGE-BPA & 340.45 & Precursor & 825 \\
Bis Glycidyl Methacrylate & Bis-GMA & 512.65 & Major oligomer & $334-27$ \\
Bis Phenol A & BPA & 228.31 & Precursor & 215 \\
Camphoroquinone & CAMP & 166.24 & Photo-absorber & 3111 AJ \\
Ethoxylated Bis Phenol A Dimethacrylate & E-BPA & 452.59 & Precursor & PB-1774 \\
Glycidyl Methacrylate & GMA & 142.17 & Precursor & $274-16$ \\
1,6-Hexane diol Dimethacrylate & HDDM & 286.36 & Monomer & $887-315-2$ \\
N,N Dihydroxyethyl-p-toluidine & DHEpT & 420.59 & Accelerator & $359-16-9$ \\
N,N Dimethylaminoethyl Methacrylate & DMAEM & 352.10 & Accelerator & $* 71919$ \\
Tri Ethylene Glycol Dimethacrylate & TEGDMA & 286.36 & Diluent oligomer & $334-2$ \\
Urethane Dimethacrylate & UDMA & 498.69 & Major oligomer & $326-28$ \\
\hline
\end{tabular}

* Koch-Light Laboratories, Colnbrook Buck, England.

All other chemicals were supplied by Esschem, Essington, PA.

were: benzoyl peroxide, methylmethacrylate, ethyleneglycol dimethacrylate, TEGDMA, Bis-glycidyl methacrylate, and 2,2-bis4-methacryloxyethoxy phenyl propane. Additionally, ethanol was capable of forming peroxides of lipids. The second study, by Fujisawa et al. (1988), reported that TEGDMA binds to liposomes. They hypothesized that odontoblast processes in dentinal tubules are damaged by this binding to the cell lipid bilayer. If the actions of these chemicals are primarily on the cell membrane, this would lead to increased permeability of the cell membrane and exposure of internal plasma membranes to even more of these chemicals. The subsequent swelling of the cell due to permeability and the action of free radicals, including the lipid hydroperoxides, on cellular DNA and protein, ineluding enzymes, would inhibit the synthetic processes (Cotran et al., 1989). In the present study, the gradual inhibition of enzymatic processes suggests that DNA and protein synthetic processes were affected by a particular resin component to about the same extent.

When spectra of visible light were run through stock solutions and dilutions of stock solutions in water, it was verified that all stock preparations, except E-BPA, went into solution. This stock suspension, $0.3 \mathrm{~mol} / \mathrm{L}$ E-BPA in DMSO, showed slight turbidity, indicating that not all of it was dissolved. However, subsequent dilutions of this suspension were soluble. It is not known how the cell experiences colloidal or particulate materials, i.e., if after internalization the cell must solubilize particulates for them to have an effect, or if in endocytotic vesicles the material has less of an effect.

Leaching from resin composites may occur at two points in time: during the setting period of the resin, and later when the resin is degraded. Leaching during the first process is related to the degree of conversion or the chaining of the oligomer into a polymer (Ruyter and Øysaed, 1987; Rueggeberg and Craig, 1988; Ferracane and Condon, 1990). Future research should address how much of each of the components leach and what this represents in terms of $\mu \mathrm{g} / \mathrm{mL}$ concentration in the microenvironment of the cell. After polymerization, hydrolytic degradation over a longer period of time is also capable of releasing resin material. Tissue, bacterial, and salivary esterases are capable of hydrolyzing significant percentages from these polymers (Øysaed and Ruyter, 1986; Freund and Munksgaard, 1990).

\section{REFERENCES}

BAUME, L.J. and FIORE-DONNO, G. (1968): Response of the Human Pulp to a New Restorative Material, J Am Dent Assoc 76:1016-1022.

BERGENHOLTZ, G.; COX, C.F.; LOESCHE, W.J.; and SYED, S.A. (1982): Bacterial Leakage Around Dental Restorations: Its Effect on the Dental Pulp, J Oral Pathol 11:439-450.

BLOCK, W.W.; AUSTIN, J.C.; CLEATON-JONES, P.E.; WILTON-COX, H.; and FATTI, L.P. (1977): Pulpal Response to a New Visible Light-cured Composite Restorative Material: Fotofil $($ J J Oral Pathol 6:278-287.

BRÄNNSTRÖM, M. and NYBORG, H. (1972): Pulpal Reaction to Composite Resin Restorations, $J$ Prosthet Dent 27:181-189.

COTRAN, R.S.; KUMAR, V.; and ROBBINS, S.L. (1989): Pathologic Basis of Disease, Philadelphia: W.B. Saunders Co., pp. 1-38.

COX, C.F.; KEALL, C.L.; KEALL, H.J.; OSTRO, E.; and BERGENHOLTZ, G. (1987): Biocompatibility of Surface-sealed Dental Materials against Exposed Pulps, J Prosthet Dent 57:1-8.

DARNELL, J.; LODISH, H.; and BALTIMORE, D. (1986): Molecular Cell Biology, New York: W.H. Freeman and Company, pp. 105-129.

FERRACANE, J.L. and CONDON, J.R. (1990): Rate of Elution of Leachable Components from Composite, Dent Mater 6:282-287.

FREUND, M. and MUNKSGAARD, E.C. (1990): Enzymatic Degradation of Bis-GMA/TEGDMA Polymers Causing Decreased Microhardness and Greater Wear in vitro, Scand J Dent Res 98:351-355.

FUJISAWA, S.; KADOMA, Y.; and KOMODA, Y. (1988): ${ }^{1} \mathrm{H}$ and ${ }^{\mathrm{I} 3 \mathrm{C}} \mathrm{NMR}$ Studies of the Interaction of Eugenol, Phenol and Triethyleneglycol Dimethacrylate with Phospholipid Liposomes as a Model System for Odontoblast Membranes, $J$ Dent Res 67:1438-1441.

GOSSELIN, R.E.; SMITH, R.P.; and HODGE, H.C. (1984): Clinical Toxicology of Commercial Products, 5 th ed., Baltimore: Williams and Wilkins, p. I-2.

GUESS, W.L; ROSENBLUTH, S.A.; SCHMIDT, B; and AUTLAN, J. (1965): Agar Diffusion Method for Toxicity Screening of Plastics on Cultured Cell Monolayers, J Pharm Sci 54:1545-1547.

HANKS, C.T.; CRAIG, R.G.; DIEHL, M.L.; and PASHLEY, D.H. (1988): Cytotoxicity of Dental Composites and Other Materials in a New in vitro Device, J Oral Pathol 17:396-403.

HENSTEN-PETTERSEN, A. and HELGELAND, K. (1981): Sensitivity of 
Different Human Cell Lines in the Biologic Evaluation of Dental Resinbased Restorative Materials, Scand J Dent Res 89:102-107.

LU, F.C. (1985): Basic Toxicology: Fundamentals, Target Organs, and Risk Assessment, New York: Hemisphere Pub., p. 104.

NASJLETI,C.E.; CASTELLI, W.A.; and CAFFESSE, R.G. (1983): Effects of Composite Restorations on the Periodontal Membrane of Monkeys, $J$ Dent Res 62:75-78.

ØYSAED, H. and RUYTER, I.E. (1986): Water Sorption and Filler Characteristics of Composites for Use in Posterior Composites, $J$ Dent Res 65:1315-1318.

RATHBUN, M.A.; CRAIG, R.G.; HANKS, C.T.; and FILISKO, F.E. (1991): Cytotoxicity of a bis-GMA Dental Composite before and after Leaching in Organic Solvents, J Biomed Mater Res 25:443-457.

RUEGGEBERG, F.A and CRAIG, R.G. (1988): Correlation of Parameters Used to Estimate Monomer Conversion in a Light Cured Composite, $J$ Dent Res 67:932-937.

RUYTER, I.E. and ØYSAED, H. (1987): Composites for Use in Posterior Teeth: Composition and Conversion, $J$ Biomed Mater Res 21:11-23.

STANLEY, H.R.; BOWEN, R.L.; and FOLIO, J. (1979): Compatibility of
Various Materials with Oral Tissues. II. Responses to Composite Ingredients, J Dent Res 58:1507-1517.

STANLEY, H.R.; GOING, R.E.; and CHAUNCEY, H.H. (1975): Human Pulp Response to Acid Pretreatment of Dentin and to Composite Restoration, $J$ Am Dent Assoc 91:817-825.

STANLEY, H.R.; SWERDLOW, H.; and BUONOCORE, M.G. (1967): Pulp Reactions to Anterior Restorative Materials, J Am Dent Assoc 75:132141.

TERAKADO, M.; YAMAZAKI, M.; TSUJIMOTO, Y.; KAWASHIMA, T.; NAGASHIMA, K.; OGAWA, J.; FUJITA, Y.; SUGIYA, H.; SAKAI, T.; and FURUYAMA, S. (1984): Lipid Peroxidation as a Possible Cause of Benzoyl Peroxide Toxicity in Rabbit Dental Pulp—a Microsomal Lipid Peroxidation in vitro, J Dent Res 63:901-905.

TOBIAS, M.; CATALDO, E.; SHIERE, F.R.; and CLARK, R.E. (1973): Pulp Reaction to a Resin-bonded Quartz Composite Material, $J$ Dent Res 52:1281-1286.

WENNBERG, A.; HASSELGREN, G; and TRONSTAD, L. (1979): A Method of Toxicity Screening of Biomaterials using Cells Cultured on Millipore Filters, J Biomed Mater Res 13:109-120. 